УДК 347.9

DOI https://doi.org/10.32782/2524-0374/2021-11/39

ПОНЯТТЯ СТОРІН У ЦИВІЛЬНОМУ ПРОЦЕСІ

\title{
THE CONCEPT OF THE PARTIES IN CIVIL PROCEDURE
}

\author{
Єфімова А.О., студентка IV курсу юридичного факультету
}

Дніпропетровський державний університет внутрішніх справ

Гуня В.M., студентка IV курсу юридичного факультету Дніпропетровський державний університет внутрішніх справ

\author{
Поліщук М.Г., к.ю.н., доцент, \\ доцент кафедри цивільно-правових дисциплін \\ Дніпропетровський державний університет внутрішніх справ
}

У статті розглянуто особливості правового статусу позивача та відповідача в цивільному процесі. Розглянуто права та обов'язки сторін цивільного процесу та обґрунтовано принцип рівності сторін. Розкрито проблему визначення неналежної сторони цивільного процесу. Роз'яснено, що рівність прав та обов'язків сторін полягає в тому, що обидві сторони мають рівне право захищати свої права особисто або через представників. Право позивача на подання позову відповідає праву відповідача на подання заперечення проти позову та подання зустрічного позову з метою захисту своїх прав. Зазначено, що процесуальні права сторін пов'язані з процесуальними обов'язками. Установлено, що важливою ознакою, яка характеризує суб'єктивне цивільне процесуальне право, є його тісний органічний зв'язок із процесуальними обов'язками осіб, які мають права.

Проаналізовано, що задля належного здійснення прав процесуальний закон визначає порядок, способи та межі їх здійснення зводячи їх до рангу процесуальної відповідальності. Установлено, що однією з актуальних проблем судочинства є проблема захисту процесуальних прав, особливо зловживання процесуальними правами. Роз'яснено, що безпосередньо сторони змушені звертатися за захистом до суду через спір та невизначеність матеріальних правовідносин. Зазначено також, що спір може виникнути і за відсутності таких відносин у дійсності, тому юридичним суб'єктом сторін можуть бути особи, які лише вважають, що між ними є матеріально-правовий зв'язок. Проаналізовано позиції сторін процесу, які тісно пов'язані з кримінальним правопорушенням. Визнано, що сторони мають особистий юридичний інтерес у справі, що розглядається судом, який буде протилежним за матеріально-процесуальним характером.

Ключові слова: позивач, відповідач, сторони, неналежна сторона, особи, які беруть участь у цивільному провадженні, судовий збір, звільнення від судового збору, сплата судового збору.

The article considers the peculiarities of the legal status of the plaintiff and defendant in civil proceedings. The rights and obligations of the parties to the civil proceedings are considered and the principle of equality of the parties is substantiated. The problem of determining the improper side of the civil process is revealed. It is clarified that the equality of rights and obligations of the parties is that both parties have an equal right to protect their rights personally or through representatives. The plaintiff's right to sue corresponds to the defendant's right to object to the lawsuit and to file a counterclaim in order to protect his rights. It is noted that the procedural rights of the parties are related to their procedural obligations. It has been established that an important feature that characterizes subjective civil procedural law is its close organic connection with the procedural responsibilities of persons who have rights. It is analyzed that for the proper exercise of rights the procedural law determines the procedure, methods and limits of their exercise, thus reducing them to the rank of procedural responsibility. It is established that one of the urgent problems of the judiciary is the problem of protection of procedural rights, and especially the abuse of procedural rights. It was clarified that the parties are directly forced to seek protection in court due to the dispute and the uncertainty of the material legal relationship. It is also noted that a dispute may arise in the absence of such a relationship in reality, so the legal entity of the parties may be persons who only believe that there is a substantive relationship between them. The positions of the parties to the process, which are closely related to the criminal offense, are analyzed. It is recognized that the parties have a personal legal interest in the case before the court, which will be the opposite of the substantive nature.

Key words: plaintiff, defendant, parties, improper party, persons involved in civil proceedings, court fees, exemption from court fees, payment of court fees.

Вступ. Обов'язковим складником цивільного процесу $\epsilon$ наявність у ньому учасників, тобто суб'єктів, які називаються особами і які беруть участь у справі. Це поняття характеризує третіх осіб - прокурора, позивача, відповідача та інших зацікавлених осіб у справах особливого провадження, які виникають із громадських правових відносин.

Головними серед них і незамінними, безперечно, $є$ позивач і відповідач. Сторонами справи позначаються особи, між якими $є$ цивільно-правова суперечка, яка не вирішилась на добровільній основі і підлягає розгляду в суді.

Із визначення випливає, що два учасники мають протилежні матеріально-правові інтереси. Іншими словами, між ними відбувається суперечка про право та інтереси.

Розглянемо докладніше ці поняття. Позивач - це особа, з ініціативи і у вигляді заяви якої порушується кримінальна справа задля захисту іiї прав та законних інтересів. Заяву подає сам зацікавлений громадянин, а також це може бути прокурор, держоргани чи профспілки. Незалежно від того, ким є позивач, він буде у суді суб'єктом спірного права. Для правильного визначення процесуального положення позивача необхідно враховувати те, в чиїх інтересах відбувається ця суперечка

Метою статті є аналіз поняття сторін у цивільному процесі.

Аналіз публікацій, у яких започатковано розв'язання цієї проблеми. Правильне визначення поняття сторін має вагоме практичне значення, адже $\epsilon$ необхідною умовою для ефективного i, що головне, однакового застосування судами норм цивільного процесуального законодавства, що регламентують процесуальний правовий статус цих учасників цивільного процесу. Базові теоретичні дослідження поняття та процесуального правового статусу сторін у цивільному процесі зроблено ще в 60-80-х роках минулого століття. Тоді ж ця проблематика активно піддавалася науковому аналізу багатьма вченими, як-от М.А. Вікут, Н.М. Васильченко, М.А. Гурвич, П.Ф. Єлісейкін, Н.Б. Зейдер, О.В. Іванов, А.А. Мельников, Л.М. Орлова, С.Г. Пушкар, А.Ф. Клейнман, В.К. Пучинський, К.С. Юдельсон, В.М. Семенова, М.Х. Хутиз, Н.О. Чечіна, Д.М. Чечот, М.С. Шакарян, М.Й. Штефан, В.Н. Щеглов та інші. Їхні праці не втратили свого значення й нині. Серед сучасних дослідників ці питання розкрито в розвідках М.I. Балюка, С.С. Бичкової, С.В. Васильєва, Л.Є. Гузя, Я.П. Зейкана, В.В. Комарова, 
B.М. Кравчука, Д.Д. Луспеника, О.І. Угриновської, С.Я. Фурси, Є.І. Фурси, М.Х. Хутиза, Ю.С. Червного та ін.

Виклад основного матеріалу. Як відомо, суб'єкти цивільних процесуальних правовідносин - це учасники процесуальних відносин, які виникають у суді щодо розгляду і вирішення цивільних справ. Усіх учасників цивільного процесу прийнято класифікувати на певні групи залежно від стосунку до справи, яка розглядається судом, та процесуальної ролі, котра визнається за ними у цій справі. Щодо визначення поняття сторін, то між процесуалістами ще з радянських часів триває дискусія, яка зводиться до конфлікту двох основних позицій [1, с. 13-17].

Відповідно до першої позиції сторонами є особи, між якими виник матеріально-правовий спір [2, с. 121]. Згідно 3 другою позицією сторони є ймовірними суб'єктами спірного матеріального правовідношення [3, с. 59]. Ця дискусія збереглась і серед сучасних науковців.

Наприклад, С.Я. Фурсою сторони визначено як осіб, що беруть участь у справі від свого імені та 3 метою захисту своїх прав та інтересів, спір між якими про їхні суб'єктивні права й обов'язки має бути вирішено судом. Після наведеної дефініції автор звертає увагу на те, що сторони на момент подання позову $є$ передбачуваними суб'єктами [4, с. 135].

Однак визначення сторін як передбачуваних учасників спірних матеріальних правовідносин критикується B.B. Комаровим, який зазначає, що така постановка питання суперечить законодавству. Учений стверджує, що основним у характеристиці сторін $€$ те, що останні $є$ учасниками правового спору, переданого для розгляду суду [5, c. 292-293].

Ю.В. Білоусов також зазначає, що сторонами слід визнати осіб, матеріально-правовий спір між якими $\epsilon$ предметом судового розгляду в порядку цивільного судочинства [6, с. 53].

Незважаючи на популярність серед сучасних процесуалістів першої концепції розуміння поняття сторін, більш обгрунтованими вважаємо аргументи прихильників другої позиції $[10 ; 11]$.

Досліджуючи цивільний процесуальний правовий статус осіб, які беруть участь у справах позовного провадження, С.С. Бичкова зазначає: «Хоча поняття «сторони» має безпосередній зв'язок із матеріальними правовідносинами, однак поняття сторін у цивільному процесі не $€$ тотожним поняттю сторін матеріальних правовідносин, оскільки за результатами розгляду й вирішення правового спору суд може встановити той факт, що сторони цивільної справи не є суб'єктами цих правовідносин». Тобто ідентифікація осіб як сторін цивільної справи не пов'язана 3 попереднім визнанням їх учасниками матеріальних правовідносин, хоча такий зв'язок, безперечно, існує $[7$, с. $75-80]$.

Уважаємо, що для відповіді на питання щодо поняття сторін доцільно визначити характерні ознаки цих суб'єктів цивільних процесуальних правовідносин. У юридичній літературі в різний час висловлювалися різноманітні погляди шодо цього.

Зауважимо, що ще за радянських часів у публікації процесуалістів С.Ю. Каца, Л.Я. Носко (1982 рік) зазначалося, що сторони в процесі характеризуються такими ознаками: сторони - це суб'єкти матеріального правовідношення з протилежними юридичними інтересами; процес ведеться від їхнього імені, їхні розпорядчі дії можуть здійснювати вирішальний вплив на виникнення й розвиток процесу в справі; рішення суду, як правило, поширюється на сторони; судові витрати в справі у випадках та розмірах, указаних у законі, покладаються на сторони [8, с. 47].

Пізніше (у 1999 році) М.О. Вікут та I.М. Зайцев характерними ознаками сторін назвали такі: наявність протилежних юридичних інтересів, ведення процесу від свого імені; постановлення судового рішення щодо сторін, поширення сили судового рішення на сторони, покладення на сторони судових витрат [9, с. 72].

М.Й. Штефан характерними ознаками сторін називав такі: ними є особи, між якими виник спір про цивільне право; вони ведуть процес у справі від свого імені; щодо їхньої справи судом виноситься рішення; на них поширюються всі правові наслідки законної сили судового рішення; вони несуть судові витрати; їх правосуб'єктність допускає процесуальне правонаступництво. Процесуально-правовий стан сторін визначається принципом рівноправності [10, с. $85-86]$.

У контексті цього питання ознаками сторін, які відрізняють їх від інших суб'єктів цивільних процесуальних правовідносин, та осіб, які беруть участь у справі, названо такі: сторони - це обов'язкові суб'єкти цивільного процесу в справах позовного й наказного провадження; сторони - це особи, між якими виник спір про право, що є предметом розгляду й вирішення судом; юридична зацікавленість сторін має особистий характер, тобто вони наділені і матеріально-правовою, і процесуальною заінтересованістю; справа (процес) ведеться від імені сторін; сторони несуть судові витрати в справі; на сторони поширюються всі наслідки та властивості рішення суду; правосуб'єктність сторін допускає правонаступництво.

У наукових джерелах виокремлюють такі ознаки сторін:

- виникнення між ними матеріально-правового спору стало підставою для відкриття провадження в справі;

- саме цей спір є предметом розгляду й вирішення в цивільному процесі;

- у них наявні протилежні інтереси, що зумовлює їх протистояння одна одній;

- вони завжди спрямовуються на захист власних прав, свобод та інтересів;

- вони зацікавлені в результатах розгляду цивільної справи;

- вони діють у процесі від свого імені;

- вони можуть брати участь у цивільній справі через представника;

- щодо розв'язання їх спору судом ухвалюється рішення;

- на них поширюються всі правові наслідки законної сили цього рішення;

- на них покладається обов'язок 3 оплати судових витрат;

- у встановлених законом випадках їх можуть замінювати процесуальні правонаступники [11, с. 69].

Наведене свідчить про те, що вказане питання залишається не вирішеним у юридичній доктрині. Незважаючи на дещо відмінні позиції науковців щодо переліку характерних рис сторін як основних учасників цивільного процесу, можна констатувати також наявність багатьох схожих ознак, які ними виокремлюються. Зокрема, аналіз вищевказаних та інших доктринальних і нормативних джерел дозволяє зробити висновок, що визначальною ознакою сторін (як учасників процесу) слід визнати особисту юридичну заінтересованість у результатах справи.

Ця ознака визнається більшістю дослідників. Заінтересованість сторін $є$ своєрідною, адже вона зачіпає особисту сферу, оскільки саме сторони є суб'єктами матеріального правовідношення, що припускаються. Саме їх зв'язок із допроцесуальними правовідносинами додає такій заінтересованості суб'єктивного відтінку. Причому особиста юридична заінтересованість має і матеріально-правову, і процесуальну спрямованість, як-от заінтересованість в отриманні сприятливого матеріально-правового результату і заінтересованість у можливості участі в процесі [12, с. 39].

Матеріально-правовий інтерес визначається спірними матеріальними правовідносинами, суб'єктами яких є, ймовірно, сторони. Процесуальний інтерес сторін визначається матеріально-правовим інтересом та полягає в тому, що кожна сторона прагне отримати рішення суду, зміст якого відповідав би її вимогам. 
Юридична заінтересованість у справі грунтується на законі прагнення сторони отримати судовий захист порушеного (оспорюваного) суб'єктивного права або охоронюваного законом інтересу [13, с. 71]. 3 огляду на це, юридична заінтересованість сторін у переданий на розгляд суду справі завжди є протилежною за матеріальним і процесуальним характером.

Юридична заінтересованість визначає ще одну ознаку сторін, за якою процес у справі ведеться від їхнього імені та в їхніх інтересах навіть тоді, коли позивач особисто не порушує справу або сторони особисто не присутні в судовому засіданні. Як слушно зазначається в літературі, залежно від характеру судового розгляду зазнає змін сфера їхніх особистих і матеріальних прав [16, с. 39-40], оскільки справа ведеться в інтересах сторін, адже лише ïx наділено правами щодо зміни й припинення процесу в справі і тільки на сторони поширюється матеріальноправова сила судового рішення.

Так, сторони примушує шукати захисту в суді, як правило, спірність і невизначеність матеріальних правовідносин. Однак правовий спір може мати місце за відсутності таких відносин, наприклад, у разі помилкового уявлення про наявність між особами спірних правовідносин. Тому правосуб'єктність сторін можуть мати особи, які лише вважають, що між ними є матеріально-правові відносини Якби в усіх випадках подання позову вимоги ініціатора процесу грунтувалися на дійсних спірних матеріальних правовідносинах, у всіх справах суди постановляли б рішення про задоволення позову, а також не існувало б інституту заміни неналежного відповідача.

3 огляду на це, слушною видається позиція С.С. Бичкової, яка вказує, що цивільним процесуальним правовим статусом сторін у цивільному процесі наділяються як імовірні, так і дійсні суб'єкти як імовірного, так і дійсного спірного матеріального правовідношення. Оскільки дійсність спірного матеріального правовідношення, а також дійсність його суб'єктів установлюється судом у процесі розгляду й вирішення цивільної справи, то автор визначає сторони як імовірних суб'єктів імовірного спірного матеріального правовідношення [11, с. 99-100].

Таким чином, сторонам (як основним учасникам цивільного процесу) більш притаманна ознака ймовірності, а не наявності реального спору про право.

Участь у справі особисто або через представника можуть брати не лише сторони, а й інші особи, які є учасниками справи. Відповідно до ст. 53 ЦПК таким правом поряд зі сторонами наділено третіх осіб - осіб, які захищають права, свободи чи інтереси інших осіб відповідно до закону, а також заявників та інших заінтересованих осіб у справах окремого провадження (крім справ про усиновлення).

Тому вказана ознака також не дозволяє відмежувати сторони від інших осіб, які беруть участь у справі.

Щодо тягаря судових витрат, то від сплати судового збору звільняються позивачі за подання позовів про стягнення заробітної плати, поновлення на роботі та за іншими вимогами, що постають із трудових правовідносин; за подання позовів про відшкодування шкоди, заподіяної каліцтвом або іншим ушкодженням здоров'я, а також смертю фізичної особи; за подання позовів про стягнення аліментів тощо (згідно 3 правилом ст. 5 Закону України «Про судовий збір» [14]). Згідно з положенням ч. 1 ст. 136 ЦПК суд, ураховуючи майновий стан сторони, може відстрочити або розстрочити сплату судового збору на визначений строк у порядку, передбаченому законом, але не більше як до ухвалення судового рішення у справі [15]

Таким чином, на нашу думку, характерними ознаками сторін - учасників цивільного процесу можна визнати такі: - імовірність;

- наявність у сторін протилежних юридичних інтересів у процесі;

- своєрідний (подвійний) характер юридичної заінтересованості, яка має матеріально-правову та процесуальну спрямованість;

- ведення сторонами процесу від свого імені, захист власних прав, свобод та інтересів;

- можливість впливати на перебіг судового провадження, змінювати або припиняти його;

- постановлення судового рішення щодо сторін та поширення на них його сили.

3 огляду на викладене, поняття сторін як основних учасників процесу, на нашу думку, може бути сформульовано так: імовірні суб'єкти спірних матеріальних правовідносин, які беруть участь у справі з метою захисту власних прав, свобод та охоронюваних законом інтересів, прагнучи отримати судове рішення, яким закріплювався би сприятливий для них матеріально-правовий результат.

До складу сторін входять позивач і відповідач, яким притаманні всі ознаки цієї групи учасників процесу. Характер заінтересованості позивача й відповідача в справі є протилежним, адже результат процесу завжди буває вигідним лише для однієї сторони. Для позивача такий вигідний результат втілюється в задоволенні його обгрунтованого позову, а в разі пред'явлення безпідставного позову у відповідача виникає юридичний інтерес у судовому рішенні, яким позивачу в позові було би відмовлено.

Указані суб'єкти мають власні характерні ознаки: позивач завжди є ініціатором цивільного судочинства, тоді як відповідач залучається до процесу судом; позивач уважається «активною стороною», оскільки саме він висуває позовні вимоги, а відповідач - це «пасивна сторона», яка захищається від вимог позивача; процес завжди порушується в інтересах позивача, саме він на власний розсуд вказує відповідача, однак лише судом у кінцевому акті правосуддя визначається те, чи є відповідач дійсним порушником.

Висновки. Аналіз сформульованих у юридичній доктрині визначень цих суб'єктів цивільних процесуальних правовідносин дозволяє нам зробити такі висновки:

- позивач - це сторона процесу, яка вважає, що ії права порушено та (або) оспорено, і в інтересах якої ініціюється цивільний процес;

- відповідач - це сторона, яка за заявою позивача або іншого ініціатора процесу залучається судом до участі в справі як імовірний порушник прав позивача.

Підсумовуючи, зазначимо, що наведені дефініції можуть і повинні стати предметом наукової дискусії з метою пошуку такого їх досконалого формулювання, яке могло б знайти своє законодавче оформлення.

\section{ЛITEPATYPA}

1. Думич Х.М. Сторони в цивільному процесі за австрійським процесуальним кодексом 1895 р. : ознаки та правовий статус. Науковий вісник Херсонського державного університету. Серія Юридичні науки. 2016. Випуск 1. Том 1. С. 13-17

2. Гражданский процесс : учебник / под ред. проф. М.К. Треушникова. Москва : Новый Юрист, 1998. 512 с.

3. Гражданский процесс : учебник / под ред. проф. В.В. Комарова. Харьков : Одиссей, 2001. 704 с.

4. Фурса С.Я., Щербак С.В., Євтушенко О.І. Цивільний процес України : проблеми і перспективи : науково-практичний посібник. Київ : Вид. Фурса С.Я. : КНТ, 2017. 789с

5. Курс цивільного процесу : підручник / В.В. Комаров, В.А. Бігун, В.В. Баранкова та ін. ; за ред. В.В. Комарова. Харків : Право, 2011. 1352 с.

6. Цивільний процес : навч. посіб. / А.В. Андрушко, Ю.В. Білоусов, Р.О. Стефанчук та ін. Київ : Прецедент, 2005. 293 с.

7. Бичкова C.C. Визначення неналежної сторони у цивільному процесі України. Форум права. 2010. № 4. C. 75-80. URL: http://www.nbuv.gov.ua/e-journals/FP/2010-4/10bcccpu.pdf (дата звернення 05.11. 2021) 
8. Советский гражданский процесс / под общ. ред. С.Ю. Каца, Л.Я. Носко. Київ : Вища школа, 1982. 423 с.

9. Викут М.А. Зайцев И.М. Гражданский процесс России. Москва : Юристъ, 1999. 384 с.

10. Штефан М.Й. Цивільний процес : підручник / вид. 2-е, перероб. та доп.. Київ : Ін Юре, 2001. 696 с.

11. Цивільний процесуальний кодекс України : [наук.-практ. коментар / [С.С. Бичкова, Ю.В. Білоусов, В.І. Бірюков та ін.] ; за заг ред. С.С. Бичкової. 2-е вид., доп. і перероб. Київ : Атіка, 2018. 896 с.

12. Тертишніков В.І. Цивільний процесуальний кодекс України : науково-практичний коментар. Харків : Видавець ФОП Вапнярчук Н.M., 2007. 576 с.

13. Проблеми теорії та практики цивільного судочинства : монографрія / В.В. Комаров, В.І. Тертишніков, В.В. Баранкова та ін. ; за заг. ред. В.В. Комарова. Харків : Харків юридичний, 2008. 928 с.

14. Про судовий збір : Закон України від 28 листопада 2013 року. URL : http://zakon2.rada.gov.ua/laws/show/3674-17. (дата звернення 05. 11. 2021).

15. Цивільний процесуальний кодекс України : Закон України від 18 березня 2004 року № 1618-IV // (В редакції Закону № 2147-VIII від 03.10.2017, BBP, 2017, № 48, ст.436). URL: http://zakon0.rada.gov.ua/laws/show/1618-15 (дата звернення 05.11. 2021). 